\title{
Recycled Newsprint Laws and Differential Taxation of the Press
}

\author{
Richard Madris†
}

Several states and municipalities have recently passed laws that require newspaper publishers to use a specified minimum percentage of recycled newsprint. ${ }^{1}$ These recycled newsprint laws represent "a response to the glut of newspapers collected by communities seeking to reduce the volume of solid waste they must burn or bury." Requiring newspaper publishers to use recycled paper presumably enlarges the market for such scrap, eliminates the stockpile of old newspapers, and decreases the need for new landfills. ${ }^{3}$ The public's heightened awareness of environmental issues and the continued surplus of collected newspapers may lead more states to consider such recycling laws in the future.

Recycled newsprint laws raise a number of important questions under the First Amendment. ${ }^{4}$ First Amendment concerns arise because of the potential impact of the laws on newspaper circulation. Just as taxes decrease the level of consumption of the

† B.S. 1991, Cornell University; J.D. 1994, The University of Chicago.

1 Newsprint is the paper on which newspapers are printed. Mandatory recycled newsprint requirements have been enacted by (among others) California, Cal Pub Resources Code $\S \S 42750-42791$ (West 1986 and Supp 1994); Connecticut, Conn Gen Stat Ann $\S \S 22 a-256 m$ through 22a-256u (West 1985 and Supp 1993); Wisconsin, Wis Stat Ann $\S 159.31$ (West 1989 and Supp 1993); Missouri, Mo Ann Stat § 260.255 (Vernon 1990 and Supp 1993); Maryland, Md Environment Code Ann § 9-1707 (Michie 1993); the District of Columbia, DC Code \$ 6-3419-6-3422 (Michie 1981 and Supp 1993); Arizona, Ariz Rev Stat Ann $\S 49-834$ (West 1988 and Supp 1993); North Carolina, NC Gen Stat § 105-102.6 (Michie 1992); and Suffolk County, New York, Suffolk County L § 399-13 (1990). See also Michael Parrish, Debate Flares Over Push to Recycle Newspapers, LA Times D1 (June 2, 1990).

2 Congress Should Scrap Dingell's Recycling Plan, Newsday 64 (July 10, 1992) (editorial). These used papers, collected through curbside recycling programs, are not currently recycled into new newspapers.

3 "[T]he purpose of the bill is to promote markets for old newspapers ...." Jim Puzzanghera and Dan Fagin, Newsprint Bill Kindles Debate, Newsday 4 (May 31, 1990) (quating James Tripp of the Environmental Defense Fund).

4 The First Amendment provides that "Congress shall make no law . . . abridging the freedom of speech, or of the press." The Fourteenth Amendment extends this restriction to the states. See Gitlow v New York, 268 US 652, 666 (1925); Near v Minnesota, 283 US 697,707 (1931). 
taxed commodity by raising its consumer end price, ${ }^{5}$ recycled newsprint laws raise the price of newspapers and may result in a decline in newspaper circulation or a reduction in the number of pages printed. In either case, the laws decrease the amount of information disseminated to the public. ${ }^{6}$ Environmental regulation in the form of recycled newsprint laws could thus have a severe impact on public discourse. ${ }^{7}$ This Comment addresses these concerns and argues that recycled newsprint laws are unconstitutional under the First Amendment because they result in differential taxation of the press.

In defining the scope of differential taxation, ${ }^{8}$ the Supreme Court has held that tax laws targeting the press are presumptively unconstitutional under the First Amendment. ${ }^{9}$ Recycled newsprint laws single out newspapers by requiring newspaper publishers, and only newspaper publishers, to purchase recycled newsprint. And because recycled newsprint costs more than virgin paper, ${ }^{10}$ that regulatory burden is effectively equivalent to a tax. Under the Supreme Court's differential taxation rulings, therefore, recycled newsprint laws appear presumptively unconstitutional under the First Amendment.

Section I of this Comment briefly describes selected state and county recycled newsprint regulations. Section II discusses the relevant case law and shows that differential regulatory treatment of the press is subject to strict scrutiny under the First Amendment. Section III argues that recycled newsprint laws

5 See Minneapolis Star and Tribune Co. $v$ Minnesota Commissioner of Revenue, 460 US 575, 590-91 n 14 (1983); Richard J. Pierce, Jr., The Constitutionality of State Environmental Taxes, 58 Tulane L Rev 169, 205 (1983).

${ }^{6}$ A $15 \%$ increase in the price of newspapers will cause approximately a $7.5 \%$ decrease in circulation. See Robert Cooter and Thomas Ulen, Law and Economics 30 (HarperCollins, 1988); Barnaby J. Feder, The Media Business, NY Times D6 (Nov 9, 1992) (noting a $17 \%$ loss in newsstand sales for newspapers that had raised prices).

7 Newspapers play an enormous role in the marketplace of ideas in America. The daily newspaper circulation is over 100 million, compared to a combined average daily audience of 40 million for the newscasts of the three major networks. See George Comstock, The Evolution of American Television 102 (Sage, 1989).

8 Differential taxation of the press is defined as taxing members of the media in a manner different from that customarily accorded non-media businesses. See Comment, Minneapolis Star \& Tribune Co. v. Minnesota Commissioner of Revenue: Differential Taxation of the Press Violates the First Amendment, 69 Iowa L Rev 1103, 1106 (1984).

${ }^{9}$ See Minneapolis Star, 460 US at 585.

${ }^{10}$ See Deborah A. Boerner, Recycling the Paper Forest, American Forests 37, 42 (July/Aug 1990) (noting in an accompanying editorial note that recycled stock is generally "prohibitively expensive"). The relative prices of recycled newsprint and virgin newsprint are continuously in flux as a result of changing pressures on supply and demand. Id. See also Julian Allen, What Price 'the Only Game in Town'?, 216 Paper 27 (Sept 3, 1991). 
cannot survive this scrutiny. The Section then proposes alternatives that do not violate the Constitution. In particular, states and localities can legitimately serve their environmental interests by adopting general economic regulations that require all paper users, not just newspapers, to meet recycled content goals.

\section{STATE AND LOCAL RECYCLED NEWSPRINT LAWS}

No federal laws regulate the composition of newsprint. ${ }^{11}$ States and counties, however, are forging ahead with their own recycled newsprint requirements. ${ }^{12}$ Currently, publishers have agreed to voluntary plans in New York, Pennsylvania, Vermont, Massachusetts, and Michigan, and voluntary agreements have been discussed in Kentucky, New Jersey, and other states. ${ }^{13}$ More importantly for the purposes of this Comment, over twenty states have enacted coercive legislation forcing newspaper pub-

"Congressman John Dingell, chairman of the House Energy and Commerce Committee, sponsored HR 3865, which would have required newspapers to use newsprint that contains at least $35 \%$ recycled fiber by 1995 and $50 \%$ by 2002 . See National Waste Reduction, Recycling, and Management Act, HR Rep 102-839, 102d Cong, 2d Sess 54 (Aug 11, 1992). See also Recycling Bill Targets Papers, Newsday 19 (July 2, 1992). A paper that failed to comply would be required to print on the front page a notice that the newspaper "does not meet the federal government's required percentage of recycled content." Id. Although approved by the House Energy and Commerce Committee, Dingell's bill has not become law. Previous federal bills have also foundered in committee. For example, in 1991, Senator Helms sponsored S 805, which would have promoted the recycling of newsprint by requiring major newspaper publishers to use an average of $40 \%$ recycled newsprint per year by the year 2000. S 805, 102nd Cong, 1st Sess (Apr 11, 1991), in 137 Cong Rec S 4349. The year before, Representative Slaughter had introduced HR 4575, which would have amended the tax code to allow newspaper publishers a credit against income tax for using recycled newsprint. HR 4575, 101st Cong, 2nd Sess (Apr 19, 1990), in 136 Cong Rec H 1615. Neither became law.

${ }_{12}$ See Parrish, Debate Flares at D1 (cited in note 1). See also the statutes collected in note 1. Although all the various recycled newsprint laws require newspapers to use a minimum amount of recycled content, the laws use different means to achieve this goal. Many states impose fines if a target percentage is not met. See, for example, Conn Gen Stat Ann $\S 22 a-2560$. Wisconsin charges newspapers a fee for each ton of newsprint used, but offers a credit for each ton of recycled newsprint used. See Wis Stat Ann $\S 159.31$. In addition, Missouri requires newspaper publishers to report their recycled content and sets target percentages, but does not impose a fine for failure to meet the target. See Mo Ann Stat § 260.255. These variations do not impact the analysis of this Comment, because all of the laws share an important feature: they single out newspapers for a burden that no other business must bear.

${ }^{13}$ Parrish, Debate Flares at D1. Some of these "voluntary" agreements may not be so voluntary-that is, publishers may enter into them to forestall coercive legislation. For example, in Oregon's Multnomah County, a ballot drive for mandatory recycled newsprint was derailed only after the publisher of the Portland Oregonian agreed to a voluntary plan. Id. 
lishers to use paper containing recycled fiber. ${ }^{14}$ Many of these laws single out large newspapers and apply only to newsprint and not to other paper.

Two such laws have achieved national prominence. California's Integrated Waste Management Act of $1989^{15}$ requires all newspapers distributed in California to contain at least 50 percent recycled paper by the year $2000 .{ }^{16}$ The statute sets out the following timetable: a newspaper must be comprised of 25 percent recycled newsprint by 1991 ; 30 percent by 1994; 35 percent by $1996 ; 40$ percent by 1998 ; and 50 percent by $2000 .{ }^{17}$ Similarly, an ordinance of Suffolk County, New York ${ }^{18}$ requires that by the end of 1996, every newspaper distributed or sold in Suffolk County be printed on paper that is 40 percent recycled. ${ }^{19}$ Some recycled newsprint laws exempt newspapers with small circulations. For example, Wisconsin's statute does not apply to newspapers with a circulation under $20,000,{ }^{20}$ while the Missouri recycled newsprint law does not apply to newspapers with an average daily distribution of 15,000 copies or less. ${ }^{21}$

In general, recycled newsprint laws carry stiff penalties for failing to use recycled paper. The standard fine is $\$ 50$ per ton, which is roughly equivalent to ten percent of the value of the paper used..$^{22}$ In Connecticut, the fine for noncompliance can be as high as $\$ 100,000 .^{23}$ The Suffolk County Law is enforceable by a $\$ 500$ fine for each day a newspaper publishes in violation of the law's requirements. ${ }^{24}$ To monitor compliance, Suffolk County officials plan to visit publishing plants inside and outside Suffolk

\footnotetext{
14 See Allen, 216 Paper at 27 (cited in note 10).

15 Cal Pub Resources Code $\S \S 42750-42791$.

16 Id at $\$ 42761$.

17 Id at $\$ \S 42760-42761$.

18 Suffolk County L $\S \S 399-10-399-18$ (1992).

19 Suffolk County L \& 399-13(A)(6).
}

${ }^{20}$ Wis Stat Ann $\S 159.31(4)$ (c). Suffolk County may have a similar exemption. Formerly, the exemption appeared at Suffolk Law $\S 399-13(A)(4)$, a subsection that has since been repealed. However, Suffolk County Legislator Maxine Postal, the sponsor of the most recent version of the Suffolk statute, maintains that the exemption is still considered part of the County Code. Telephone conversations with Maxine Postal and Paul Sabatino, counsel to the Suffolk County Legislature (Feb 4, 1994) (memorandum on file with U Chi $\mathrm{L}$ Rev) (claiming the deletion was probably inadvertent).

21 Mo Ann Stat \& 260.255(1).

22 See Allen, 216 Paper at 27 (cited in note 10).

23 Gen Stat Conn $\S 22 a-2560$.

${ }^{24}$ Suffolk County L $\S 399-16$. See also Puzzanghera and Fagin, Newsprint Bill Kindles Debate at 4 (cited in note 3 ). 
County to conduct spot checks on newsprint fiber content and also to ask publishers to certify compliance. ${ }^{25}$

\section{DifFerential TAXation OF THE PRESS}

Although there are no cases directly on point, ${ }^{26}$ other First Amendment cases addressing taxation and regulation of the press shed light on the constitutionality of recycled newsprint laws. This Section discusses the differential-treatment precedents, highlighting the different standards applied to generally applicable regulation cases on the one hand and to differentialtaxation cases on the other. It then argues that the differentialtaxation standard has been extended to other types of differential economic regulation of the press and should be extended to recycled newsprint laws as well.

\section{A. The First Amendment Framework}

Different types of state-imposed speech regulations are analyzed under different levels of constitutional scrutiny. Government regulations affecting speech are often classified as either "content based" or "content neutral." Content-based restrictions limit expression because of the communicative impact of the speech. ${ }^{28}$ In order for a content-based regulation to survive, the government generally must show that the statute is narrowly tailored to achieve a compelling state interest. ${ }^{29}$ This "strict scrutiny"30 test has been used to invalidate statutes in a variety of

25 Id.

${ }^{25}$ One reason courts have not yet considered the constitutionality of mandatory recycled newsprint laws is that many of the recycled newsprint requirements do not take full effect until 1996 or later. But as the deadlines approach, publishers will likely seek relief. Other factors can also delay judicial scrutiny of these laws. For example, the Republican county executive of Suffolk County has simply refused to enforce the county's recycled newsprint law enacted by the Democratic legislature. Telephone conversations (cited in note 20).

${ }_{27}$ See Laurence H. Tribe, American Constitutional Law $\$ 12-2$ (Foundation, 2d ed 1988).

${ }^{28}$ See Geoffrey R. Stone, Content-Neutral Restrictions, 54 U Chi L Rev 46, 47 (1987).

${ }^{29}$ See Widmar $v$ Vincent, 454 US $263,268-70$ (1981). The government may also satisfy its burden by proving that the speech affected falls within an "unprotected" category of expression. These unprotected categories include speech likely to incite imminent lawless action, Brandenburg v Ohio, 395 US 444, 447 (1969); obscenity, Miller v California, 413 US 15, 20 (1973); and some forms of defamation, Gertz $v$ Welch, 418 US 323, 34748 (1974).

${ }^{30}$ The strict scrutiny test originated in the Supreme Court's equal protection jurisprudence. In a concurring opinion in Simon \& Schuster, Inc. $v$ New York State Crime Victims Board, 112 S Ct 501, 513 (1991), Justice Kennedy traced the migration of the 
freedom of expression cases. ${ }^{31}$ In contrast to content-based laws, content-neutral restrictions limit communication without regard to the content of the message conveyed. ${ }^{32}$ Content-neutral statutes are generally given greater deference by the courts, which often apply a less demanding standard in such cases. ${ }^{33}$

Like content-neutral statutes, tax laws affecting only newspapers burden speech without regard to its communicative effect. Yet the Supreme Court has often compared statutes imposing special tax burdens on the press to statutes in the content-based category. ${ }^{34}$ In Minneapolis Star and Tribune Co. $v$ Minnesota Commissioner of Revenue, the Court noted that statutes that apply only to the press have a large potential for abuse and thus are analogous to content-based restrictions. ${ }^{35}$ Similarly, in Leathers $v$ Medlock, the Court compared a tax targeting a small number of speakers to a content-based regulation, concluding that both "distort the market for ideas." Differential taxation of the

strict scrutiny standard to First Amendment analysis. For a discussion of Simon \& Schuster, see text accompanying notes 74-76. For a discussion of the longstanding debate over the appropriate approach in content-based cases, see Gerald Gunther, Constitutional Law 1069-70 (Foundation, 12th ed 1991).

31 Relatively recent examples of the First Amendment application of strict scrutiny include Metromedia, Inc. $v$ San Diego, 453 US 490 (1981) (striking down an ordinance that prohibited billboards containing certain noncommercial speech); Widmar, 454 US 263 (striking down a university policy prohibiting the use of university buildings for religious purposes); Boos $v$ Barry, 485 US 312 (1988) (striking down a law prohibiting certain public displays in front of foreign embassies).

${ }^{32}$ See Stone, $54 \mathrm{U}$ Chi L Rev at 48 (cited in note 28).

${ }^{33}$ See Tribe, American Constitutional Law at § $12-8$ (cited in note 27). One commentator has argued that a careful review of the Supreme Court's decisions reveals three distinct standards for content-neutral restrictions: deferential, intermediate, and strict review. See Stone, $54 \mathrm{U}$ Chi L Rev at 50.

${ }^{34}$ In differential taxation cases, the Supreme Court has focused its analysis on the First Amendment, rather than the Fourteenth Amendment, because the legislation implicates freedom of the press. See, for example, Arkansas Writers' Project, Inc. $v$ Ragland, 481 US 221, 227-28 n 3 (1987) ("First Amendment claims are obviously intertwined with interests arising under the Equal Protection Clause... [but] since Arkansas's sales tax system directly implicates Freedom of the Press, we analyze it primarily in First Amendment terms."); Minneapolis Star, 460 US at 585-86 n 7 (viewing the differential taxation problem as "arising directly under the First Amendment"). The dissent in Minneapolis Star argued that differential taxation should be subject to scrutiny only under the Equal Protection Clause. Id at 598-600 (Rehnquist dissenting). However, the majority explicitly rejected this argument. Id at 585-86 n 7. See also Geoffrey $R$. Stone, Content Regulation and the First Amendment, $25 \mathrm{Wm}$ \& Mary L Rev 189, 206 (1983) ("The degree of scrutiny that is appropriate in [testing] content-based restrictions [is] fundamentally a First Amendment issue. Invocation of the Equal Protection Clause adds nothing constructive to the analysis.").

${ }^{35} 460$ US 575, 582 (1983) (holding such taxes "cannot stand unless the burden is necessary to achieve an overriding governmental interest").

36499 US 439, 448 (1991). 
press does not seem to fit neatly into either the content-neutral or the content-based framework, and perhaps is best understood as falling within this separate, hybrid category. ${ }^{37}$

No matter how they are classified, the differential-taxation cases receive the highest level of scrutiny from the Court. Taxes aimed at the press are subject to strict scrutiny..$^{38}$ In contrast, strict scrutiny is not applied to general economic regulations that merely affect the press. ${ }^{39}$ The difference between such generally applicable economic regulations and differential taxation is critical to evaluating the constitutionality of the recycled newsprint laws.

\section{Generally applicable economic regulations.}

Congress and the States can subject newspapers to generally applicable economic regulations $\mathrm{s}^{40}$ and tax legislation ${ }^{41}$ without creating constitutional problems. For example, in Associated Press $v$ NLRB, the Court upheld the application of the National Labor Relations Act ("NLRA") to the Associated Press news service. ${ }^{42}$ After discharging an employee for his membership in a labor organization, the Associated Press argued that the First Amendment shielded it from the NLRA, which prohibits employers from discharging employees for labor activities. ${ }^{43}$ The Court

${ }^{37}$ Stone places the differential taxation cases by themselves in a strict-scrutiny subcategory of content-neutral review. Stone, $54 \mathrm{U}$ Chi $\mathrm{L}$ Rev at $53 \mathrm{n} 31$ (cited in note 28).

${ }^{38}$ See, for example, Minneapolis Star, 460 US at 582 (applying strict scrutiny because "Minnesota has singled out the press for special treatment"); Arkansas Writers' Project, 481 US at 227 ("Our cases clearly establish that a discriminatory tax on the press burdens rights protected by the First Amendment.").

${ }^{39}$ See, for example, Minneapolis Star, 460 US at 581 ("It is beyond dispute that the states and the federal government can subject newspapers to generally applicable economic regulations without creating constitutional problems.").

${ }^{10}$ The Supreme Court "has recognized the strong governmental interest in certain forms of economic regulation, even though such regulation may have an incidental effect on rights of speech and association." NAACP v Claiborne Hardware Co., 458 US 886, 912 (1982). See also California Motor Transport Co. $v$ Trucking Unlimited, 404 US 508, 514-15 (1972) (holding anticompetitive activity is not immunized from trade-practice regulation because it is engaged in by members of the communications industry).

1 See University of Pennsylvania $v$ EEOC, 493 US 182, 200 (1990) (noting that a university can be subjected to a generally applicable tax without violating its First Amendment right to academic freedom); Jimmy Swaggart Ministries $v$ Board of Equalization, 493 US 378, 387-88 (1990) (holding that the imposition of a general sales and use tax on a religious organization's distribution of religious materials does not violate the Religion Clauses of the First Amendment); Branzburg $v$ Hayes, 408 US 665, 683 (noting that the First Amendment is not violated by nondiscriminatory forms of general taxation upon the press).

301 US 103, 130 (1937).

${ }^{43}$ Id at 131. See also 29 USC $\S 151$ (1988). 
held that the First Amendment does not prohibit all regulation of the press: "The business of the Associated Press is not immune from regulation because it is an agency of the press. The publisher of a newspaper has no special immunity from the application of general laws. He has no special privilege to invade the rights and liberties of others." ${ }^{\prime 44}$

Following Associated Press, the Court has held that general regulatory schemes, such as antitrust laws, ${ }^{45}$ the Fair Labor Standards Act, ${ }^{46}$ and health and safety regulations ${ }^{47}$ can be applied to the press without raising significant First Amendment concerns. In Arcara $v$ Cloud Books, for example, the Court upheld the application of the New York Public Health Law to a bookstore. ${ }^{48}$ New York authorities shut down an adult bookstore pursuant to a law that authorized the forced closure of a building for one year if it had been used for the purpose of lewdness, assignation, or prostitution. ${ }^{49}$ The application of the statute to the bookstore did not violate the First Amendment because all buildings, and not just bookstores, were subject to the regulation. ${ }^{50}$

\section{Differential taxation.}

Since 1936, the Court has found economic regulations aimed exclusively at protected speakers to be unconstitutional under the First Amendment. In Grosjean $v$ American Press Co., Inc., the Court struck down a Louisiana tax affecting only thirteen out of 137 publications in the state. ${ }^{51}$ The thirteen newspapers, each of which had weekly circulations over 20,000, were singled out in an attempt to punish Senator Huey Long's political enemies-the large newspapers in Louisiana. ${ }^{52}$ The Court noted that the tax would limit the newspapers' circulation, and that if increased, the tax could eliminate the papers altogether. ${ }^{53}$ Grosjean made it clear that the First Amendment prohibits statutes that apply only to selected speakers. ${ }^{54}$ Although the legislative purpose of

44301 US at 132-33.

45 Citizen Publishing Co. v United States, 394 US 131, 139-40 (1969).

${ }^{46}$ Oklahoma Press Publishing Co. $v$ Walling, 327 US 186, 192-93 (1946).

47 Arcara v Cloud Books, Inc., 478 US 697, 707 (1986).

48 Id at 699, 707.

49 Id at 699. There was no claim in Arcara that any books in the store were obscene. Id at 698 .

so Id at 705 .

51297 US 233, 240-41, 251 (1936).

${ }^{52}$ See Note, First Amendment Limits on the Use of Taxes to Subsidize Selectively the Media, 78 Cornell L Rev 106, 109 (1992).

${ }^{53} 297$ US at 244-45.

54 Following Grosjean, two state courts struck down regulations that burdened the 
punishing Huey Long's enemies may have accounted in part for the Court's decision, the Court implied that any laws reducing newspaper circulation were constitutionally suspect. Indeed, the Supreme Court's subsequent differential taxation cases have not even required an improper legislative motive.

Minneapolis Star declared that improper motive is not a necessary part of a First Amendment challenge. ${ }^{55}$ In Minneapolis Star, the Supreme Court struck down a Minnesota use-tax on the sale of large quantities of newsprint and ink. ${ }^{56}$ The use-tax exempted the first $\$ 100,000$ of paper and ink for each publisher, so the burden of the tax fell almost exclusively on large newspapers. ${ }^{57}$ Striking down both the Minnesota use-tax and its exemption on First Amendment grounds, the Court held that: (1) the press cannot be singled out from other businesses for the imposition of special burdens and (2) taxes cannot be imposed on some members of the press but not on others. ${ }^{58}$

The first part of this holding acts as a prophylactic rule to guard against the dangers of differential treatment of the press. In dissent, Justice Rehnquist argued that the newspapers had paid less under the special tax than they would have paid under Minnesota's general tax scheme. ${ }^{59}$ However, the majority was not concerned with the size of the burden. Instead, the majority focused on the potential for legislative abuse "[w]hen the state singles out the press, [because] the political constraints that prevent a legislature from passing crippling taxes of general applicability are weakened, and the threat of burdensome taxes becomes acute." ${ }^{\circ 0}$ In contrast, generally applicable laws force governments to impose the same burden on a wide range of con-

press. A Florida court invalidated a license tax that increased with circulation, concluding that Grosjean prohibited any tax on the press based on circulation. City of Tampa $v$ Tampa Times Co., 153 Fla 709, 711, 15 S2d 612, 613 (1943). A Maryland court also struck down a tax imposed on buyers of advertising in media. City of Baltimore v A.S. Abell Co., 218 Md 273, 288-89, 145 A2d 111, 119 (1958).

s5 460 US at 592. In Simon \& Schuster, the Court reaffirmed that "[i]llicit legislative intent is not the sine qua non of a violation of the First Amendment." $112 \mathrm{~S} \mathrm{Ct}$ at 509, quoting Minneapolis Star, 460 US at 592.

56 Minneapolis Star, 460 US at 577-78, 593. Minnesota had imposed a $4 \%$ tax on the cost of paper and ink products exceeding $\$ 100,000$ used in the production of a publication. Id at $578 \mathrm{n} 2$.

${ }^{57}$ Id at 578. Because of this exemption, only 16 of the State's 374 newspapers were subject to the tax in 1975 . Id at 579.

s8 "[The differential] tax violates the First Amendment not only because it singles out the press, but also because it targets a small group of newspapers." Id at 591.

${ }_{59}$ Id at 598 (Rehnquist dissenting).

60 Id at 585. 
stituents, reducing opportunities for abuse. ${ }^{61}$ Unwilling to rely on a case-by-case approach to separate laws that burdened First Amendment actors from laws that benefitted them, the Court concluded that any tax statute singling out the press was presumptively unconstitutional. ${ }^{62}$

The second part of the holding addressed the additional problems of applying different tax treatment to different members of the press. The small-newspaper exemption to the Minnesota use-tax provided an independent basis for striking down the statute because the exemption had the effect of limiting the tax to a few large newspapers. ${ }^{63}$ For the same reasons that the press must be treated like other businesses, the Court held that different newspapers must be treated alike. The Court stated that a tax scheme singling out only a few members of the press "presents such a potential for abuse that no [state interest] can justify the scheme."64

Relying on Minneapolis Star, the Court has held that a statute cannot impose different tax burdens on different publications according to their subject matter. In Arkansas Writers' Project, Inc. $v$ Ragland, the Court struck down a state sales tax statute that applied to general-interest magazines but not to newspapers or specialized journals. ${ }^{65}$ Noting that the sales tax applied to some but not to all magazines, and that only three publications paid sales tax under the statute, the Court held that Minneapolis

61 One commentator has suggested an additional problem with differential taxation: "[A sound] reason for making constitutionally suspect any formal singling out of the press [is] to protect the political neutrality of the press ... [and to] prevent the government from undermining the [neutrality of the press] by forcing [it] to engage actively in the political process in order to protect its own self-interest." Randall P. Bezanson, Political Agnosticism, Editorial Freedom, and Government Neutrality Toward the Press: Observations on Minneapolis Star and Tribune Co. v. Minnesota Commission of Revenue, 72 Iowa L Rev 1359, 1371 (1987). See also Rob Bennett, Taxing the Marketplace of Ideas, 51 Tax Notes 1317 (June 10,1991) (noting that political intrigue is a likely source of differential taxation).

62 "Differential taxation of the press, then, places such a burden on the interests protected by the First Amendment that we cannot countenance such treatment unless the State asserts a counterbalancing interest of compelling importance that it cannot achieve without differential taxation." Minneapolis Star, 460 US at 585. The Court provided the following justification for its ruling: "There is substantial evidence that differential taxation of the press would have troubled the Framers of the First Amendment.... The fears of the [Framers] were well founded. [The] threat [of differential taxation] can operate as effectively as a censor to check critical comment by the press . . . " Id at 583-85.

63 Id at 591-92.

64 Id at 592.

65481 US 221, 224 (1987). Specialized journals included religious, professional, trade, and sports magazines. Id. 
Star prohibited such a tax. ${ }^{66}$ Although the tax did not discriminate among particular points of view, it applied only to certain subject areas and therefore triggered strict scrutiny. The Court stressed that differential treatment of the press-either the press as a whole or individual members of the press-posed particular dangers of governmental abuse. ${ }^{67}$

Although tax statutes must not single out the press or individual members of the press, a state can exempt some members of the press, but not others, from a generally applicable tax. In Leathers $v$ Medlock, the Court upheld a broad-based Arkansas sales-tax scheme that taxed cable television but not magazine and newspaper sales. ${ }^{68}$ Applying a differential-taxation analysis, the Court concluded that the tax scheme did not single out the press because it applied to the sale of all tangible personal property as well as a broad range of services. ${ }^{69}$ Although newspapers were not included, the statute's broad application provided some safeguard against the potential for abuse present in the earlier cases. $^{70}$

In Leathers, the Court restated its general presumption against differential taxation of the media, noting that tax statutes that (1) single out the press, (2) target small groups of speakers, or (3) discriminate on the basis of the content of taxpayer speech, are subject to strict scrutiny under the First Amendment. ${ }^{71}$ The Leathers test thus combines the established principles of both Minneapolis Star and Arkansas Writers' Project. $^{72}$

As these differential-taxation cases illustrate, states are prohibited from singling out the press as a whole or members of the press for special tax burdens. Most recycled newsprint laws target only newspapers. Therefore, whether the strict scrutiny mandated by Leathers will apply to the recycled newsprint con-

66 Id at 234.

67 Id at 228.

68 499 US 439 (1991). The sales and use tax in question applied to a broad range of non-media services, including utilities, telecommunications, lodging, maintenance, printing, and ticket distribution. See Ark Code Ann § 26-52-301 (Michie 1992).

69499 US at 447.

${ }^{30}$ Id.

71 Id.

72 For an application of Leathers, see Globe Newspaper Co. $v$ Commissioner of Revenue, 410 Mass 188, 571 NE2d 617 (1991) (using the Leathers analysis to invalidate a sales-tax scheme that subjected newspaper publishers to different tax treatment than other manufacturers). 
tent laws depends on whether the differential tax cases extend to cover other forms of economic regulation.

\section{B. Differential-Tax Cases Apply to Economic Regulations}

Although most Supreme Court cases in the area of "differential taxation" involve tax statutes, some have involved other sorts of economic regulations targeting the press. ${ }^{73}$ In fact, the Supreme Court recently applied differential-taxation analysis to a content-based regulation that was not a tax. In Simon \& Schuster v New York State Crime Victims Board, the Court invalidated New York's "Son of Sam" law, which compensated crime victims with the confiscated proceeds of books written by criminals describing their crimes. ${ }^{74}$ The statute violated the first and third prongs of the Leathers test: it singled out income derived from expressive activity for a regulatory burden that the State placed on no other income, and applied only to works about a specified subject. ${ }^{75}$ New York attempted to distinguish the Son of Sam law from the tax in Arkansas Writers' Project by arguing that Arkansas Writers' Project was limited to tax statutes. The Court rejected this argument, holding that a regulation placing income from speech in escrow should be treated similarly to an outright tax. "Both forms of financial burden operate as disincentives to speak; indeed, in many cases it will be impossible to discern in advance which type of regulation will be more costly to the speaker."76

The Court has equated regulation with taxation in other differential taxation cases as well. In Arkansas Writers' Project, Justice Scalia dissented precisely because the majority assumed that, for First Amendment purposes, the denial of an exemption from taxation is equivalent to regulation. ${ }^{77}$ Furthermore, Leathers drew an analogy between tax statutes and labor laws. Although labor laws were not tax laws, the Court found that they

73 A formalistic court might draw a distinction between taxes and regulations in the differential taxation cases. However, courts have in fact approached this issue on a functional basis and have at times treated non-tax regulations as analytically equivalent to differential taxation regulations.

${ }^{74} 112$ S Ct 501, 504-05, 512 (1991), citing NY Exec Law $\S 632$-a (McKinney 1982 and Supp 1994).

75 Simon \& Schuster, $112 \mathrm{~S} \mathrm{Ct}$ at 509.

76 Id at 508-09.

77 See Arkansas Writers' Project, 481 US at 236 (Scalia dissenting). 
could be compared to taxes because both involved government action that placed burdens on members of the press. ${ }^{78}$

In addition, several lower courts have explicitly stated that economic regulation of the press and taxation of the press should be treated similarly under the First Amendment. In Associated Film Distribution Corp $v$ Thornburgh, the Third Circuit used differential-taxation analysis to consider the validity of a Pennsylvania statute regulating the exhibition and production of motion pictures. ${ }^{79}$ The court held that the statute, which sought to eliminate unfair business practice in the industry, was a contentneutral application of the state's general regulation of unfair business practices. ${ }^{80}$ In reaching this conclusion, the court stated that "[t]he rationale of Minneapolis Star may require its extension beyond taxation to regulations that impose differential penalties directly on some First Amendment activity. Certainly, some regulation may in effect control the activity regulated as effectively as would taxation." 81

Similarly, other courts have extended Minneapolis Star to non-tax regulation that imposes differential penalties directly on First Amendment activity. For example, in $J-R$ Distributors, Inc. $v$ Eikenberry, the Ninth Circuit followed Minneapolis Star and invalidated a statute that imposed fines based on the profits generated from the exhibition of obscene movies. ${ }^{82}$ The court concluded that noncompliance fines that increase in proportion to the extent of the prohibited activity are similar to use-taxes and therefore invalid, absent a compelling state interest. ${ }^{83}$

This extension of the differential taxation standard to other forms of regulation finds support in the language of Minneapolis Star. There, the Court provided examples of economic regulation $^{84}$ and concluded that "a regulation that singled out the press [would] place a heavier burden of justification on the State . . . " Indeed, the Court placed the words "tax" and "eco-

${ }^{78}$ Leathers, 499 US at $452-53$.

79800 F2d 369, 373-75 (3d Cir 1986).

so Id at 374-75. The Supreme Court relied on a similar theory in California Motor Transport, 404 US at 514-15.

${ }^{81}$ Associated Film, 800 F2d at 374 (citations omitted).

82 725 F2d 482, 495-96 (9th Cir 1984) ("The Court's reasoning [in Minneapolis Star] is as applicable to fines as taxes."), rev'd on other grounds as Brockett v Spokane Arcades, Inc., 472 US 491 (1985).

${ }_{83} J \cdot R$ Distributors, 725 F2d at $495-96$.

\& For example, the Court noted that the Fair Labor Standards Act is an economic regulation. 460 US at 583, citing Oklahoma Press, 327 US 186.

${ }_{85}$ Minneapolis Star, 460 US at 583. 
nomic regulation" in parallel sentence structure: "Any tax that the press must pay, of course, imposes some 'burden.' But, as we have observed, this Court has long upheld economic regulation of the press." The Court's use of "tax" and "regulation" interchangeably in Minneapolis Star indicates that a "tax" and a "regulation" should be treated similarly for purposes of the First Amendment.

Moreover, lower courts have extended Minneapolis Star to other forms of regulation because it makes sense to do so. Regulation can limit an activity as effectively as taxation. ${ }^{87}$ Like taxes, most regulations increase the costs of newspaper operations, and the burdens imposed by regulations can be augmented by the legislature. ${ }^{88}$ Indeed, regulations can be more burdensome to apply than taxes and can lead to more litigation. ${ }^{89}$ Therefore, the differential taxation cases have appropriately been extended to require strict scrutiny of other cases involving the economic regulation of the press.

\section{APPLication OF THE CASE LAW TO RECYCLED NEWSPRINT LAWS}

\section{A. Strict Scrutiny Applies to Recycled Newsprint Laws}

Recycled newsprint laws are a form of economic regulation and should therefore be treated like a tax on publishers. These laws raise the cost of producing newspapers by effectively taxing all expenditures for newsprint. Because, like a tax, recycled content laws impose a burden that can be increased at the discretion of the legislature and can be augmented by additional regulations of a similar type, they present the same dangers presented by

${ }^{86}$ Id (emphasis added). The Court was not endorsing differential economic regulation, but merely noting that the cases upholding regulations emphasize the general applicability of the challenged regulation to all businesses. Id.

${ }_{87}$ Terry M. Dinan, Implementation Issues for Marketable Permits: A Case Study of Newsprint, $4 \mathrm{~J}$ Reg Econ 71 (1992) (explaining how permit requirements act as a tax on the newsprint industry). For an empirical confirmation of this point, see Robert $A$. Androkovich and Kenneth R. Stollery, Tax Versus Quota Regulation: A Stochastic Model of the Fishery, $73 \mathrm{Am} \mathrm{J} \mathrm{Ag} \mathrm{Econ} 300$ (1991).

Indeed, some states admit that their recycled newsprint laws are effectively taxes. For example, North Carolina calls its statute a "license tax on producers of newsprint publications," and the law is codified under "Taxation" in NC Gen Stat $\S 105-102.6$. The Wisconsin legislature also considers recycled newsprint laws to be equivalent to a tax. See Wis Stat Ann \& 159.31(b)(1)(b).

See Grosjean, 297 US at 244-45; Minneapolis Star, 460 US at 590-91 n 14.

89 Stephen Breyer, Taxes as a Substitute for Regulation, 10 Growth and Change 39, 48,52 n 18 (Jan 1979). 
differential taxation of the press. Recycled newsprint laws are precisely the type of laws requiring an extension of the differential taxation principles, and the Leathers test should therefore apply. Under the differential-taxation standard, recycled content laws are constitutionally questionable for two reasons. First, they apply only to newspapers and not to other potential users of recycled newsprint. Second, they single out only large newspapers.

Recycled newsprint laws such as the California Act violate the first prong of the Leathers test; ${ }^{90}$ the law applies only to newspapers, and not to other recycled newsprint consumers. ${ }^{91}$ Recycled newsprint can be used in the manufacture of many other products, including cereal boxes, egg cartons, paper bags, hydromulch, tissue products, and gypsum wallboard. ${ }^{92}$ The recycled newsprint laws enacted to date do not require these other industries to use a minimum level of recycled product, ${ }^{93}$ and therefore cannot be said to represent part of a general regulatory scheme in the same way as the broad-based tax in Leathers. Because the press may not be singled out to bear special burdens, these laws are subject to strict scrutiny under the First Amendment.

It makes sense to apply strict scrutiny to recycled newsprint laws because they single out newspapers for significant financial burdens. ${ }^{94}$ Recycled content laws limit the ability of users to respond flexibly to particular costs and constraints. ${ }^{95}$ Because these laws prohibit newspapers from switching to virgin paper, the demand for recycled paper will increase. Recycled-paper man-

90 Namely, whether a statute singles out the press. See Leathers, 499 US at 447.

91 See Maria L. LaGranga, Recycling Boom Provides Too Much of a Good Thing, LA Times A1 (Dec 28, 1992) (Newspapers are the target of the only law that "tells the private sector what to do" in terms of recycling.).

92 See BNA, Groups Urge Federal Legislation to Mandate Recycled Newsprint Use, 1992 Daily Envir Rept 219 d28 (Nov 12, 1992).

${ }_{93}$ Except in the District of Columbia. See discussion at text accompanying notes 12428.

I The financial burdens include the initial costs of converting existing virgin pulp processing plants to recycling plants, as well as the higher per-ton costs of the paper produced. Allen, 216 Paper at 27 (cited in note 10). In addition, although the industry (mills) was once near the source of its supply (tree farms), recycling laws in effect move part of the source to more distant urban areas (recycling centers). Freight costs are thus substantially increased as a result. Id.

${ }_{95}$ Moreover, publishers prefer not to buy paper from the recycled market because recycled newsprint prices vary more than virgin paper. See Note, Confronting the Garbage Crisis: Increased Federal Involvement As a Means of Addressing Municipal Solid Waste Disposal, 79 Georgetown L J 567, 570 n 21 (1991), citing Office of Solid Waste, United States EPA, The Solid Waste Dilemma: An Agenda For Action 15 (1989). 
ufacturers, who often maintain regional monopolies, ${ }^{96}$ will raise their prices if their customers must buy recycled newsprint. ${ }^{97}$ In addition, recycled newsprint statutes result in an increased burden for national newspapers that will face the costs of complying with a hodgepodge of state and local statutes. ${ }^{98}$ If the national papers have to comply with various states' recycled newsprint laws, they might have to pull out of the more restrictive states. It might be prohibitively costly for a national paper like the Wall Street Journal, for example, to print a specially produced edition for distribution in a small market.

Many recycled newsprint laws also violate the second prong of Leathers, which prohibits targeting small groups of speakers. ${ }^{99}$ Exemptions for papers with circulations below a specified level effectively limit the application of these laws to the major daily papers in a region. In Minneapolis Star, the Court struck down the Minnesota use-tax, in part, because it singled out the large publishers. ${ }^{100}$

States cannot justify the small-paper exemption as an attempt to encourage fledgling local publishers, who might not be able to afford recycled paper. ${ }^{101}$ The exemption is a subsidy to selected members of the press, and Minneapolis Star prohibits such differential treatment. ${ }^{102}$ In recycled newsprint cases, as in Minneapolis Star, the exemption may induce newspapers, especially those with circulations slightly above the exemption limit, to restrict circulation in order to cut down on recycled newsprint costs or to avoid the regulation altogether. Nor can the government impose a greater regulatory burden on the larger papers just because they are more profitable. First, higher circulation may not result in greater profitability. Second, progressive taxation of the press is unconstitutional under the First Amendment because of the differential burdens that it imposes. ${ }^{103}$

96 Only 9 of the 64 newsprint mills in the United States and Canada are capable of producing newsprint made from $100 \%$ recycled fibers. See Dinan, 4 J Reg Econ at 73 (cited in note 87).

${ }^{97}$ See Parrish, Debate Flares at D1 (cited in note 1).

98 Id. A state's application of a recycled newsprint law to newspapers produced out-ofstate might also raise separate Commerce Clause issues.

99 Leathers, 499 US at 447.

100460 US at 591-92.

101 The ability of the Minneapolis Star and Tribune to bear the burden of the tax was not a factor in Minneapolis Star, for "when the exemption selects such a narrowly defined group to bear the full burden of the tax, the tax begins to resemble more a penalty for a few of the largest newspapers than an attempt to favor struggling smaller enterprises." Id at 592.

102 Id at 592-93.

103 See Richard A. Epstein, Property, Speech, and the Politics of Distrust, 59 U Chi L 
Moreover, differential regulation of the press merits strict scrutiny because if the state has the power to single out the press, it retains the power to impose additional burdens on the press. ${ }^{104}$ Minneapolis Star noted that "[ $\left.t\right]$ he threat of sanctions may deter [the] exercise [of First Amendment rights] almost as potently as the actual application of sanctions."'105 The state could, for example, increase the required recycled content to 100 percent or place other restrictions on the newspaper's production, such as the type and quality of ink used. The cumulative burden of such regulations could "impair, perhaps severely, [the] proper functioning" of the press. ${ }^{106}$ The prophylactic rule of Minneapolis Star is designed to prevent such an accumulation of burdens.

\section{B. Application Of Strict Scrutiny to Recycled Newsprint Laws}

The differential-taxation cases indicate that recycled newsprint laws should be subjected to strict scrutiny. To survive strict scrutiny, a statute must serve a compelling state interest and must be narrowly drawn to achieve that end. ${ }^{107}$ Thus, not only must the goal be very important, but the "fit" between the means and the end must be extremely tight. In practice, a statute analyzed under a strict-scrutiny standard almost always fails. ${ }^{108}$

\section{Compelling state interest.}

This subsection discusses the environmental purposes of recycled newsprint laws solely to identify a possible "compelling state interest." It does not purport to provide the final word on the potential benefits and harms of recycling and recycled content statutes; after considerable debate, environmental experts still disagree on these issues. A court evaluating a proffered state interest will have to look at the empirical data supplied by liti-

Rev 41, 86 (1992).

104 See Minneapolis Star, 460 US at 588; Bigelow v Virginia, 421 US 809, 828-29 (1975) (reasoning that a state cannot proscribe advertising for out-of-state abortion services because allowing such regulation could lead to more burdensome regulation of newspaper content).

${ }^{105}$ Minneapolis Star, 460 US at 588, quoting NAACP v Button, 371 US 415, 433 (1963).

${ }^{106}$ Bigelow, 421 US at 829.

107 Minneapolis Star, 460 US at 585; Arkansas Writers' Project, 481 US at 231.

${ }_{108}$ See Stone, $54 \mathrm{U}$ Chi L Rev at 53 (cited in note 28). However, another commentator has argued that the Court has shown that it is willing to uphold a statute reviewed under strict scrutiny in certain circumstances. See Frederick Schauer, Codifying the First Amendment: New York v. Ferber, 1982 S Ct Rev 285, 304-06. 
gants before making its decision. In any case, the state would bear the burden of proof on this issue. ${ }^{109}$

State legislatures have passed recycled newsprint laws primarily to slow down the filling of landfills. ${ }^{110}$ Landfills are in short supply, especially in the northeastern United States. ${ }^{111}$ Given the resistance to siting new landfills, legislatures have chosen recycling as a solution to the solid waste disposal problem. ${ }^{112}$ Moreover, the recycling regulations focus on paper because it accounts for 32 percent by volume of municipal solid waste, ${ }^{113}$ with newspapers alone constituting one third of the volume of discarded paper. ${ }^{114}$ In the alternative, the state may assert that these laws will protect forests or conserve energy. A court would likely face conflicting and incongruous data on these claims as well. ${ }^{115}$

Conserving landfill space may in fact not be an important enough state interest to justify recycled newsprint laws. Some evidence suggests that the dangers of landfills have been exaggerated. ${ }^{116}$ Moreover, many recycled newsprint laws simply shift landfill dumping costs from towns to newspapers. ${ }^{117}$ In-

${ }^{109}$ Arkansas Writers' Project, 481 US at 231.

${ }^{110}$ See Lynn Scarlett, A Forum: Will the U.S. Recycling Approach Work?, EPA Journal 42, 42-43 (Aug 1992). The goal of the legislation is to increase the market for recycled paper. See Suffolk County Law $\$ 399-10$ (D) ( $[$ [T] the development of additional markets for recycled newsprint."); Puzzanghera and Fagin, Newsprint Bill Kindles Debate at 4 (cited in note 3). Presumably an increased market in recycled newsprint would decrease the need for landfill space.

111 For a general discussion of landfills, see William L. Rathje, Rubbish!, The Atlantic 99 (Dec 1989).

112 See Dinan, $4 \mathrm{~J}$ Reg Econ at 72 (cited in note 87).

${ }_{113}$ Are You a Green Consumer?, Consumer Reports 704, 706 (Nov 1992).

${ }_{114}$ Witold Rybezynski, We Are What We Throw Away, NY Times Sec 7 at 5 (July 5, 1992).

115 Recycling paper does not save forests because "[t]rees used for paper are usually grown on 'tree farms' for that purpose and are harvested at sustainable rates. Virtually no paper comes from the logging of ancient, irreplaceable forests." Green Consumer? at 705; Marcia Berss, No One Wants to Shoot Snow White, Forbes 40 (Oct 14, 1991). Similarly, recycling newspapers has not been shown to save energy. "To show that recycling paper actually saves energy would require analyzing energy use for the entire lifecycle of paper made from both raw materials-pulpwood and waste paper. So far, no convincing analysis of this type has appeared." Green Consumer? at 705-06. For newsprint, collecting and transporting recycled material may actually consume more energy than can be conserved in the manufacturing process. Scarlett, EPA Journal at 42 (cited in note 110).

${ }_{118}$ According to United States Environmental Protection Agency studies, modern state-of-the-art landfills pose little risk to public health. Scarlett, EPA Journal at 43. Similarly, a Suffolk County Health Department report says that contrary to popular belief, landfills neither pollute nor contaminate groundwater. Ann Becker Bennett, The Island's Towns Team Up to Manage Waste, Long Island Business News 30 .(June 8, 1992).

${ }^{117}$ For example, Suffolk County found that: 
deed, the surplus of old newspapers can be eliminated by communities paying to have old newspapers removed. ${ }^{118} \mathrm{~A}$ more compelling state interest than easing the financial obligations of towns is required to force newspapers to bear this increased burden. ${ }^{119}$

In other contexts, the Supreme Court has refused to subordinate First Amendment rights to seemingly strong state interests. ${ }^{120}$ Therefore, it is unlikely that these environmental goals-subject as they are to so much scientific debate-provide a sufficiently compelling state interest to justify special regulation of the press. Nonetheless, in order to anticipate and rebut other objections, this Comment will assume that a state could satisfy the compelling-interest requirement.

2. Recycled newsprint laws are not narrowly tailored to achieve the state's interest.

Even if the recycled newsprint laws satisfy the compelling state interest prong, they are not narrowly tailored to serve that end. To survive strict scrutiny, the laws must be the least restrictive alternatives available to advance the state's interest. ${ }^{121}$ In

[N] ewspapers printed within the County of Suffolk constitute one of the largest sources of materials that wind up either in landfills or as part of costly programs for disposal by municipalities, the cost for which disposal has recently risen to such an extent as to endanger the fiscal viability of various municipalities located within the County of Suffolk.

Suffolk County Code $\S 399-10$ (A). See also Puzzanghera and Fagin, Newsprint Bill Kindles Debate at 4 (cited in note 3 ) (municipalities believe the Suffolk County law will bring down the per-ton cost to towns of removing newspapers).

${ }^{118}$ See Deborah Vaughn Nestor, Partial Static Equilibrium Model Of Newsprint Recycling, 24 Applied Econ 411 (1992).

11 In Minneapolis Star, raising revenue alone was not a sufficient justification for differential treatment of the press. See 460 US at 586.

120 See, for example, Landmark Communications, Inc. $v$ Virginia, 435 US 829 (1978) (state's interest in protecting the integrity of its judiciary); Nebraska Press Association $v$ Stuart, 427 US 539 (1976) (state's interest in ensuring right to fair trial for criminal defendant); Oklahoma Publishing Co. v District Court, 430 US 308 (1977) (state's interest in preserving the anonymity of juvenile offenders).

For an instance where the state interest was deemed compelling enough to overcome First Amendment objections, see Austin v Michigan Chamber of Commerce, 494 US 652, 659-60 (1990) (upholding legislation prohibiting non-media corporations from spending money to influence state elections, on the ground that the press exemption served a compelling state interest in light of the unique role of the press in providing a forum for discussion and debate).

121 "The [State] may serve its legitimate interests, but it must do so by narrowly drawn regulations designed to serve those interests without unnecessarily interfering with First Amendment freedoms." Village of Schaumburg $v$ Citizens for a Better Environment, 444 US 620, 637 (1980) (holding overbroad an ordinance prohibiting door-to-door 
dealing with recycled newsprint, less restrictive alternatives are available to the state. States could use general economic regulations to reduce the glut of recycled newsprint. Such generally applicable laws would advance environmental interests, reduce the amount of paper added to landfills, and increase the demand for recycled paper without violating the First Amendment rights of newspapers. For example, the price differential between recycled and non-recycled paper could be eliminated by taxing virginpulp harvesters. ${ }^{122}$ Such a tax would raise the price of all paper at the source and cause end-users to voluntarily substitute recycled product for virgin-pulp paper. This alternative neither singles out a few members of the press nor applies only to newspapers. Since all paper users, and not just newspapers, would bear the extra burden, such a regulatory scheme would avoid the First Amendment problems associated with differential taxation. ${ }^{123}$ Clearly, the recycled newsprint statutes currently in force could be more narrowly tailored. As enacted, they therefore fail strict scrutiny.

However, one jurisdiction has enacted an alternative paper recycling regulation that does pass constitutional muster. The District of Columbia requires newspapers to use a minimum percentage of recycled newsprint as part of a general scheme promoting the use of recycled paper. ${ }^{124}$ Strict scrutiny does not apply to this statute for two reasons. First, the statute does not single out newspapers for differential treatment. Rather, the statute specifies minimum-content percentages not only for newsprint, but also for bleached printing and writing paper, tissue products, unbleached packaging, and recycled paperboard. ${ }^{125}$ While the California Act and Suffolk County Law burden only

solicitation). See also Shelton v Tucker, 364 US 479, 488 (1960) ("The breadth of legislative abridgement must be viewed in the light of less drastic means for achieving the same basic purpose.").

${ }_{122}$ The price of virgin pulp has been held artificially low through tax subsidy of the timber industry. Nestor, 24 Applied Econ at 416 (cited in note 118). This tax advantage should be eliminated so that the price of virgin pulp (and therefore virgin paper) reflects its true cost to society. Nestor believes that removing the subsidy will have little impact on recycling because "constraints on the substitution possibilities . . . act to limit the industry's response to changes in relative prices." Id. However, the elimination of the subsidy would eventually lead to a greater supply of recycled newsprint.

123 Like the public health law in Arcara, a generally applicable regulatory regime that increases the price of virgin pulp relative to recycled paper would almost certainly survive a First Amendment challenge. See Minneapolis Star, 460 US at 581; text accompanying notes $40-50$.

124 DC Code $\S \S 6-3419$ through 6-3422 (Michie 1981 \& Supp 1993).

125 Id at $\$ 3419$. 
publishers, the DC Statute spreads its burden across a wide range of industries.

Second, the statute does not impermissibly target a subgroup of newspapers. At first glance, it appears to, because paper product users are subject to the law only if they have a circulation of at least 30,000 copies, an annual weight of at least 500 tons, or annual gross receipts of at least $\$ 100,000$ from the sale or distribution of the paper product. ${ }^{126}$ But even though small newspapers are not covered, the exemption is part of a general scheme exempting de minimis paper product users. In Mabee $v$ White Plains Publishing Co., the Supreme Court upheld just such a scheme. ${ }^{127}$ There, the Court upheld the exemption of small newspapers with primarily local distribution from the Fair Labor Standards Act of 1938 because that exemption put small papers "on a parity with other small town enterprises" that were also exempt from the Act. ${ }^{128}$ The DC Statute indicates that it is possible to regulate newsprint via a general scheme of regulation applicable to all paper users.

A final alternative to the recycled newsprint laws is to allow market forces to work unfettered. Under such a system, newspapers could gain a competitive advantage by switching to recycled paper. ${ }^{129}$ These newspapers would respond to the consumer's desire to promote environmental goals through selective purchasing. ${ }^{130}$ Indeed, surveys indicate that shoppers are willing to shop longer to find "environmentally friendly" products. ${ }^{131}$ Thus, newspapers could increase their sales by using recycled newsprint and making that fact public. ${ }^{132}$ This approach has been successful in other contexts. ${ }^{133}$

126 Id.

127327 US 178 (1946).

${ }^{128}$ Id at 184.

12 Newspaper readers concerned about the costs of disposing of old newspapers will buy papers that are published using a high percentage of recycled content. For a general discussion of the marketing benefits of being "green," see Christina Duff, "Eco-Retailers" Are Celebrating Green Holidays, Wall St J B1 (Dec 15, 1992).

${ }^{130}$ See Comment, "Environmentally Friendly" Product Advertising: Its Future Requires a New Regulatory Authority, 42 Am U L Rev 155, $155-56$ (1992).

${ }^{131}$ See id at 155 n 2, citing Regulatory Innovations Staff, US EPA, Assessing the Environmental Consumer Market 3 (1991).

${ }_{132}$ In fact, much of this information is already being made public through the work of various public interest groups. For example, the U.S. Public Interest Research Group and the National Environmental Law Center recently listed the Atlanta Journal as using the highest percentage of recycled newsprint of any major newspaper in 1992. Study: Dallas Morning News Worst, Atlanta Journal Best in Recycling, UPI (Nov 10, 1992).

${ }^{133}$ For example, Starkist tuna sales increased substantially when it stopped trapping dolphins and became "the good tuna company." Starkist enjoyed good publicity, and many 
For example, Pennsylvania recently established a program designed to stimulate markets for recycled goods. ${ }^{134}$ The state is spending several million dollars on education and publicity for a "buy recycled" goods campaign, and is also converting a former steel mill into a newspaper and magazine deinking plant. These programs are expected to increase demand for recycled newsprint throughout the production process. Pennsylvania also increases demand by buying recycled paper for its own consumption, and instructs its agencies to give preference to vendors using recycled paper. ${ }^{135}$

Although states often address a problem by piecemeal experimentation confined to one industry for a trial period, the press cannot be used to test economic regulation that does not apply to other industries. ${ }^{136}$ Regulations that encroach on First Amendment values, such as recycled newsprint laws, must use the least restrictive means to achieve the desired end. Because less-restrictive alternatives exist, recycled newsprint laws are unconstitutional.

\section{CONCLUSION}

A generally applicable recycled content law that affected newspapers would be constitutional. However, state laws that apply only to newspapers, or only to some newspapers, are unconstitutional under the First Amendment. Thus, most recycled newsprint laws are unconstitutional as presently written. States should follow the District of Columbia's example and pursue their environmental interests by enacting recycled newsprint laws that cover a broad range of industries.

competing tuna companies followed suit. See, for example, Margo Harakas, 'Dolphin-safe' Tuna Initiative Highly Effective, Calgary Herald D2 (Mar 28, 1992); Tom Sietsema, Ready, Aim, Boycott, SF Chron 1/ZZ1 (Feb 24, 1993).

${ }^{134}$ Michael J. Cleary, PA Investing in Recycling Markets, 4 E Pa Bus J 1 (Jan 1993).

135 Id; $53 \mathrm{~Pa}$ Stat $\$ 4000.1505$ (West 1994).

${ }^{136}$ See, for example, FCC $v$ League of Women Voters of California, 468 US 364, 396 (1984) (underinclusiveness as basis for striking down ban on editorializing); CommunityService Broadcasting of Mid-America v FCC, 593 F2d 1102, 1122 (DC Cir 1978) (regulation may be invalid as applied to noncommercial broadcasters but not to commercial broadcasters); Arkansas Writers' Project, 481 US at 234; Minneapolis Star, 460 US at 592. 